Available online at GSC Online Press Directory

GSC Biological and Pharmaceutical Sciences

e-ISSN: 2581-3250, CODEN (USA): GBPSC2

Journal homepage: https://www.gsconlinepress.com/journals/gscbps

(RESEARCH ARTICLE)

\title{
Effects of indiscriminate consumption of paracetamol (acetaminophen) on selected biochemical parameters in Rattus norvegicus rats
}

\author{
Emmanuel Tonbra Egoro* \\ Department of Medical Laboratory Science, Faculty of Basic Medical Sciences, Niger Delta University, P.M.B. 071, \\ Wilberforce Island, Bayelsa State, Nigeria.
}

Publication history: Received on 12 November 2020; revised on 29 November 2020; accepted on 03 December 2020

Article DOI: https://doi.org/10.30574/gscbps.2020.13.3.0373

\begin{abstract}
Paracetamol (acetaminophen) is a well-known medication for the treatment of pain and fever. The aim of this study was to assess the effects of its indiscriminate consumption on selected biochemical parameters in Rattus norvegicus rats with a view to relate the findings to humans. The data obtained from the human volunteers within the age range of 2067years revealed that paracetamol (acetaminophen) is indiscriminately consumed mainly by traders as compared with other painkillers in the study communities. Five milliliters of blood specimens were withdrawn from Rattus norvegicus rats administered with $500 \mathrm{mg} / 2 \mathrm{ml}$ paracetamol (acetaminophen) for one day, acute toxicity study (experimental group one), $50 \mathrm{mg} / 2 \mathrm{ml}$ paracetamol (acetaminophen) on daily basis for thirty days, sub-chronic toxicity study (experimental group two), 50mg/2ml paracetamol (acetaminophen) on daily basis for three days, recommended therapeutic dose (experimental group three) and control group respectively. Thereafter, aspartate aminotransferase, alanine aminotransferase, alkaline phosphatase, urea, creatinine, C-reactive protein and testosterone were measured using a spectrophotometer. The mean values of all the measured biochemical parameters in both experimental group one and two rats revealed statistically significant differences $(p<0.05)$ with experimental group three rats being exception $(p>0.05)$ as compared with that of the control group which may be suggestive of hepatic, renal, inflammatory and spermatogenesis disorders. Though the consumption of this tablet at recommended therapeutic dose was well tolerated by the rats as against its indiscriminate consumption which posed danger on the rats thus it is recommended that this tablet should be taken strictly on the prescription of a physician or health professional.
\end{abstract}

Keywords: Paracetamol (acetaminophen); Indiscriminate consumption; Effects on biochemical parameters; Rattus norvegicus rats

\section{Introduction}

Paracetamol (acetaminophen) is an aniline analgesic tablet that is mainly used for treating fever and pain [1]. Despite the evidence that Paracetamol (acetaminophen) and non-steriodal anti-inflammatory drug (NSAID) have some similar pharmacological activity this tablet is often used for the relief of mild to moderate pain [2]. This tablet which is used rectally, intravenously or orally has a lasting effects of 2-4 hours [3]. Though its administration through intravenous route which is considered safer and more effective has gained a wide spread use [4].

The metabolism of this tablet is mainly carried out by the liver while to a lesser extent by the kidney and intestine [5]. $63 \%$ of this tablet upon oral administration is metabolized in the liver by glucuronidation while $34 \%$ by sulphation. The metabolites which are soluble in water are excreted through the kidney [6].

\footnotetext{
${ }^{*}$ Corresponding author: Emmanuel Tonbra Egoro

Department of Medical Laboratory Science, Faculty of Basic Medical Sciences, Niger Delta University, P.M.B. 071, Wilberforce Island, Bayelsa State, Nigeria.
}

Copyright $(2020$ Author(s) retain the copyright of this article. This article is published under the terms of the Creative Commons Attribution Liscense 4.0. 
Studies have revealed that $\mathrm{N}$-Acetyl- $\mathrm{p}$-benzoquinoneimine is the metabolite responsible for paracetamol (acetaminophen) toxicity. In overdosing cases, glutathione stores are depleted with the subsequent elevation in the concentration of N-Acetyl-p-benzoquinoneimine [7]. Paracetamol (acetaminophen) toxicity creates acute tubular necrosis, which is responsible for one of the main causes of acute renal failure [8]. Exposure to drug toxicity produces free radicals in an organism which in turn leads to oxidative damage [9]. Its main mechanism of action is linked to its inhibitory effect on the synthesis of prostaglandins which are lipids derived from the arachidonic acid pathway that act as mediators of inflammation, fever and pain [10].

Paracetamol (acetaminophen) is often preferred to other non-steriodal anti-inflammatory drugs (NSAIDs) as it is thought less likely to cause enteropathy as a result of its relative potency as an inhibitor of prostaglandin. Overdose of this tablet if untreated may result in a prolonged painful illness with non-specific signs and symptoms such as vomiting, nausea, pain, sweating etc which may result in acute liver and possibly kidney failures [11].

This research work is aimed at the effects of indiscriminate consumption of paracetamol (acetaminophen) on selected biochemical parameters in Rattus norvegicus rats. The liver enzymes biomarkers , alanine aminotransferase, aspartate aminotransferase, and alkaline phosphatase were measured in order to assess the status of the liver taking into consideration that the liver is responsible for drug metabolism,, urea and creatinine, renal biomarkers were measured in order to assess the status of the kidneys taking into consideration that the kidneys are responsible for the excretion of waste products of metabolism and C-reactive protein, inflammatory biomarker was also measured in order to assess any inflammatory disorder that may be associated with the indiscriminate consumption of this tablet. However, all these were embarked upon with a view to relate the findings to humans.

\section{Material and methods}

\subsection{Study area}

This study with the diagram of schematic representation of workflow as shown in Figure 1 was carried out in the Department of Medical Laboratory Science, Faculty of Basic Medical Sciences, College of Health Sciences, Niger Delta University, Wilberforce Island, Bayelsa State, Nigeria

\subsection{Animal used}

The Rattus norvegicus rats used for this research work were purchased from a reputable animal house in Yenagoa, Bayelsa State, Nigeria and taken to the animal house of the Department of Medical Laboratory Science, Faculty of Basic Medical Sciences, College of Health Sciences, Niger Delta University, Wilberforce Island, Bayelsa State, Nigeria via a public transport. These rats were exposed to acclimatization in the animal house for a period of two weeks before the commencement of the study. The rats which were kept in well ventilated rat cages were fed with pre-mix rat feed and ad-libitum water.

\subsection{Ethical clearance}

This study which was carried in conformity to the National Guidelines for Animal usage in research got ethical approval from the ethical committee of Niger Delta University, Wilberforce Island, Bayelsa State, Nigeria and the leaders of National Association of Patent and Proprietary Medicine Dealers (NAPPMED) Bayelsa State branch, Nigeria. Besides, verbal informed consent was obtained from all the recruited volunteers before they were allowed to complete the questionnaire.

\subsection{Paracetamol (acetaminophen) tablet}

Packets of Emzor paracetamol (acetaminophen) tablets (500mg BP) manufactured by Emzor Pharmaceutical Industries, Plot 3C, Block A, Aswani market Road off Oshodi-Apapa Expressway, Isolo, Lagos State, Nigeria with expiry date being February, 2025 were bought in Global Pharmacy Shop located in Yenagoa, Bayelsa State, Nigeria, and stored for use for this research work in compliance with the manufacturer's instruction.

\subsection{Experimental design}

This study involved the use of two models: human and animal. 


\subsection{Inclusion and exclusion criteria}

- Apparently healthy human volunteers within the age range of 20-67years that consented to this study were used

- Volunteers who are cigarette smokers, drug addicts and are of known illness such as diabetes mellitus, hypertension etc were excluded from this study

- $\quad$ All the Rattus norvegicus rats used for this study were apparently healthy and are within the age range of 3-4 months and weight range of $103 \pm 0.05 \mathrm{~g}$. Those that were suspected of having ill health were excluded

\subsection{Human study}

The human study consisted of 384 (three hundred and eighty four) apparently healthy volunteers whose verbal informed consents were obtained. Among these volunteers 147 (one hundred and forty seven) were from AgudamaEpie community, Yenagoa, Bayelsa State, Nigeria, 128 (one hundred and twenty eight) were from Ede-Epie community, Yenagoa, Bayelsa State, Nigeria and 109 (one hundred and nine) were from Akenfa community, Yenagoa, Bayelsa State, Nigeria. The data obtained from these volunteers were via questionnaire

\subsection{Animal study}

The animal study consisted of 28 (twenty eight) male Rattus norvegicus rats of 3-4 months old with approximate weight range of $103 \pm 0.05 \mathrm{~g}$. The sample size for this study was determined utilizing the Resource Equation method in accordance with [12].

\subsection{Pilot study}

A pilot study was carried out to ascertain the minimum dose of oral consumption of paracetamol (acetaminophen) that can cause 100 percent death (LD100) and 50 percent death (LD50) respectively in the experimental Rattus norvegicus rats

A total of 16 rats having approximately the same weight of $1.23 \pm 0.05 \mathrm{~g}$ were used. These rats which were grouped into 3 with 4 rats/group were designated as A, B and C respectively with each rat in group A administered with $1500 \mathrm{mg} / 2 \mathrm{ml}$ of paracetamol (acetaminophen) $/ 1.23 \mathrm{~g}$ body weight as a single dose for one day, group B administered with 1000 $\mathrm{mg} / 2 \mathrm{ml}$ of paracetamol (acetaminophen) $/ 1.23 \mathrm{~g}$ body weight as a single dose for one day and group $\mathrm{C}$ administered with $750 \mathrm{mg} / 2 \mathrm{ml}$ of paracetamol (acetaminophen) $/ 1.23 \mathrm{~g}$ body weight as a single dose for one day and thereafter monitored for 24 hours for any signs and symptoms of paracetamol (acetaminophen) toxicity including death. The rats were considered dead when they failed to respond to agitation.

The following signs and symptoms such as convulsion, respiratory distress, coma and death occurred in 100 percent of the rats in both group A and group B (LD100) while the same signs and symptoms occurred in 50 percent of the rats in group C (LD50). The LD50 was calculated according to the arithmetic method as described by [13] and was eventually rated according to the toxicity rating method as described by [14].

After ascertaining the LD100 and LD50 twenty four Rattus norvegicus rats were now grouped as follow:

- Experimental group one: This group consisted of six Rattus norvegicus rats with weight range of $103 \pm 0.05 \mathrm{~g}$ .that were orally administered with $500 \mathrm{mg} / 2 \mathrm{ml}$ of paracetamol (acetaminophen) tablet as a single dose for one day (acute toxicity study)

- Experimental group two: This group consisted of six Rattus norvegicus rats with weight range of $103 \pm 0.05 \mathrm{~g}$ that were orally administered with $50 \mathrm{mg} / 2 \mathrm{ml}$ of paracetamol (acetaminophen) tablet on daily basis for a period of thirty consecutive days (sub-chronic toxicity study)

- Experimental group three: This group consisted of six Rattus norvegicus rats with weight range of $103 \pm 0.05 \mathrm{~g}$ that were orally administered with $50 \mathrm{mg} / 2 \mathrm{ml}$ of paracetamol (acetaminophen) tablet on daily basis for a period of three consecutive days (recommended therapeutic dose study)

- Control group: This group consisted of six Rattus norvegicus rats that were not orally administered with paracetamol (acetaminophen) tablet or any other tablet (control study)

At the end of this study, each of the experimental and control rats were anaesthetized using inhaled chloroform technique after which five milliliters blood specimen were withdrawn from their cardiac for the measurement of the following biochemical parameters. 


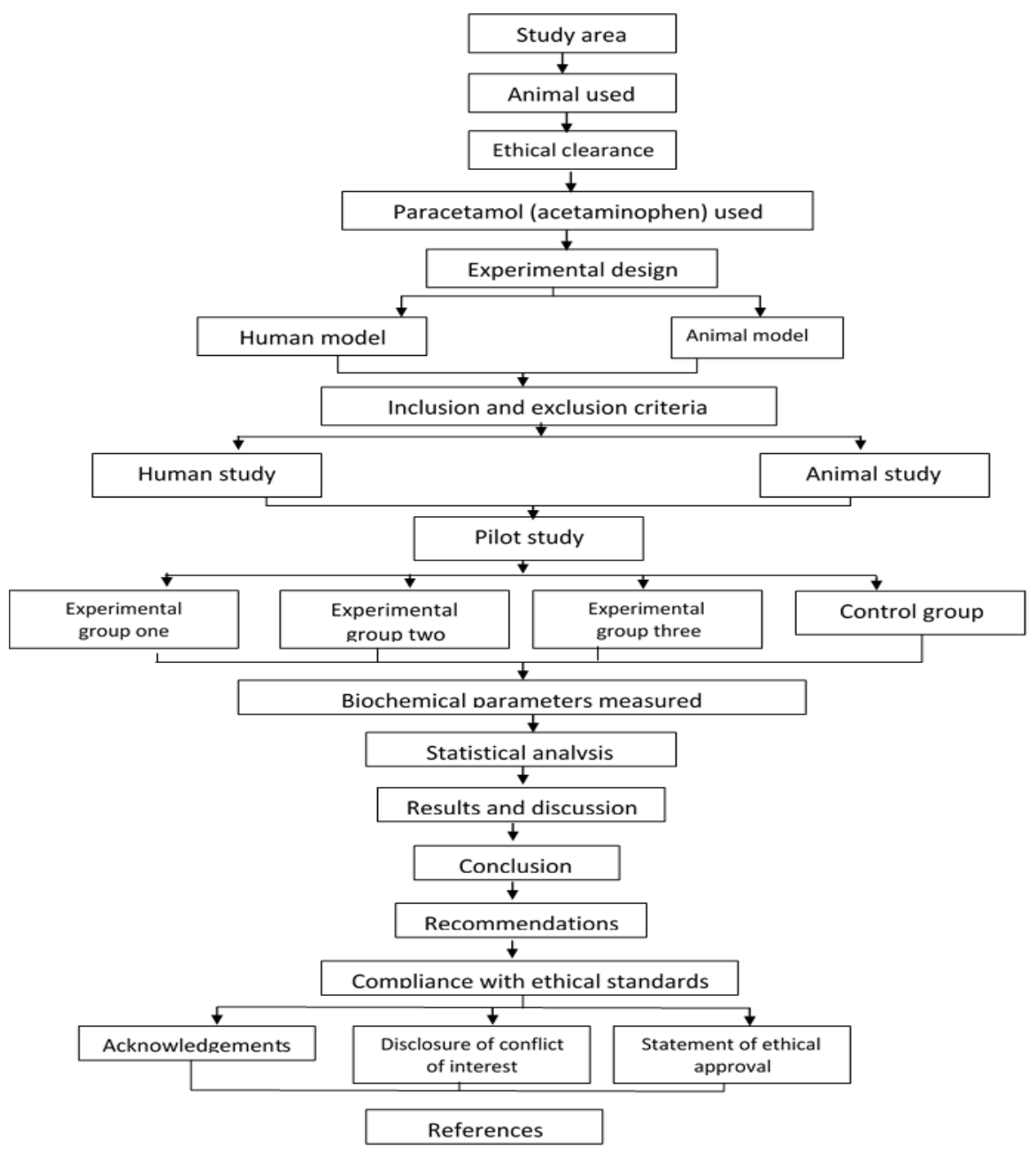

Figure 1 A diagram showing the schematic representation of workflow.

\subsection{Biochemical parameters measured with specified methods}

The absorbance of the following biochemical parameters as shown below were measured with Vis- Spectrophotometer S23A.

- Aspartate aminotransferase: In accordance with the colorimetric method as described by [15] using reagents manufactured by Randox Laboratories, Limited, 55, Diamond Road, Crumlin, County, Antrim, BT294QY, United Kingdom

- Alanine aminotransferase: In accordance with the colorimetric method as described by [15] using reagents manufactured by Randox Laboratories, Limited, 55, Diamond Road, Crumlin, County, Antrim, BT294QY, United Kingdom

- Alkaline phosphatase: In accordance with the colorimetric endpoint method as described by [15] using reagents manufactured by Teco Diagnostics, 1268N, Lakeview Avenue. Anaheim CA92807, 1-800-222-9880

- Urea: In accordance with Urease Berthelot method as described by [16] using reagents manufactured by Randox Laboratories, Limited, 55, Diamond Road, Crumlin, County, Antrim, BT294QY, United Kingdom

- Creatinine: In accordance with Jaffe reaction method as described by [16] using reagents manufactured by Randox Laboratories, Limited, 55, Diamond Road, Crumlin, County, Antrim, BT294QY, United Kingdom

- C-reactive protein: In accordance with the latex turbidimetry method as described by [16] using reagents manufactured by Spinreact Diagnostic, Spain

- $\quad$ Testosterone: In accordance with enzyme linked immunosorbent assay (ELISA) method as described by [17] using reagents manufactured by Randox Laboratories, Limited, 55, Diamond Road, Crumlin, County, Antrim, BT294QY, United Kingdom 


\subsection{Statistical analysis}

The data obtained from the volunteers via questionnaire were analyzed using descriptive statistic of frequency and percentage while the results obtained from the quantitative measurement of biochemical parameters in plasma of the Rattus norvegicus rats (control and experimental groups) were expressed as mean and standard deviation with the differences between the subjects (control and experimental groups) assessed using student ' $t$ ' test which were considered statistically significant at $\mathrm{p}<0.05$.

\section{Results and discussion}

Abuse of drugs and its addiction is one of the most challenging problems facing the society today. Painkillers are among the drugs that humans have resolved to use indiscriminately in a bid to prevent or reduce pain without the prescription of a physician or a health professional.

In this study the percentage consumption of painkillers such as paracetamol (acetaminophen), ibuprofen, panadol extra, boska, sudrex and anacin among some volunteers in Agudama-Epie, Ede-Epie and Akenfa communities in Yenagoa, Bayelsa State, Nigeria for the treatment of pain and fever were ascertained. As shown in Table 1, 70-74\% of the volunteers were established as consumers of paracetamol (acetaminophen), 8-14\% of the volunteers were established as consumers of ibuprofen, $6-10 \%$ of the volunteers were established as consumers of panadol extra, 3-6\% of the volunteers were established as consumers of boska, 2-4\% of the volunteers were established as consumers of sudrex and $1-2 \%$ of the volunteers were established as consumers of anacin. These findings have not only revealed that paracetamol (acetaminophen) is significantly consumed in the study communities, it has also gone a step further to establish its indiscriminate consumption when compared with the other painkillers used for this study a situation which is presumed to be attributed to its cheapness and ready availability in patent medicine stores.

Table 1 Percentage consumption of some painkillers in the study communities in Yenagoa, Bayelsa State, Nigeria.

\begin{tabular}{|c|c|c|c|c|c|c|c|}
\hline Communities & $\begin{array}{c}\text { Types of } \\
\text { painkillers }\end{array}$ & $\begin{array}{c}\text { Age of } \\
\text { consumers } \\
\text { (years) }\end{array}$ & $\begin{array}{l}\text { Frequency of } \\
\text { consumption }\end{array}$ & Dosage & $\begin{array}{c}\text { Period of } \\
\text { consumption } \\
\text { (months) }\end{array}$ & $\begin{array}{l}\text { Number of } \\
\text { consumers }\end{array}$ & Percentage \\
\hline \multirow{6}{*}{$\begin{array}{l}\text { Agudama- } \\
\text { Epie }(n=147)\end{array}$} & PCM & $20-67$ & Daily & Пtds & $3-6$ & 103 & 70 \\
\hline & IBR & $20-67$ & Daily & Пtds & $3-6$ & 20 & 14 \\
\hline & PAN & $20-67$ & Daily & Пtds & $3-6$ & 14 & 10 \\
\hline & BOS & $20-67$ & Daily & Пtds & $3-6$ & 5 & 3 \\
\hline & SUD & $20-67$ & Daily & Пtds & $3-6$ & 3 & 2 \\
\hline & ANA & $20-67$ & Daily & Пtds & $3-6$ & 2 & 1 \\
\hline \multirow{6}{*}{$\begin{array}{l}\text { Ede-Epie } \\
(\mathrm{n}=128)\end{array}$} & PCM & $20-67$ & Daily & Пtds & $3-6$ & 91 & 71 \\
\hline & IBR & $20-67$ & Daily & Пtds & $3-6$ & 17 & 13 \\
\hline & PAN & $20-67$ & Daily & Пtds & $3-6$ & 10 & 8 \\
\hline & BOS & $20-67$ & Daily & Пtds & $3-6$ & 5 & 4 \\
\hline & SUD & $20-67$ & Daily & Пtds & $3-6$ & 4 & 3 \\
\hline & ANA & $20-67$ & Daily & Пtds & $3-6$ & 1 & 1 \\
\hline \multirow{6}{*}{$\begin{array}{l}\text { Akenfa } \\
(\mathrm{n}=109)\end{array}$} & PCM & $20-67$ & Daily & Пtds & $3-6$ & 81 & 74 \\
\hline & IBR & $20-67$ & Daily & Пtds & $3-6$ & 9 & 8 \\
\hline & PAN & $20-67$ & Daily & Пtds & $3-6$ & 7 & 6 \\
\hline & BOS & $20-67$ & Daily & Пtds & $3-6$ & 6 & 6 \\
\hline & SUD & $20-67$ & Daily & Пtds & $3-6$ & 4 & 4 \\
\hline & ANA & $20-67$ & Daily & Пtds & $3-6$ & 2 & 2 \\
\hline
\end{tabular}

KEYS: PCM = Paracetamol (acetaminophen) tablet 500mg BP, IBR = Ibuprofen tablet 400mg BP, PAN = Panadol extra tablet: paracetamol 500mg BP and caffeine $30 \mathrm{mg}, \mathrm{BOS}=$ Boska tablet: paracetamol 500mg and caffeine 30mg, SUD = Sudrex tablet: paracetamol 500mg and caffeine 30mg, ANA = Anacin tablet $300 \mathrm{mg}$, $\prod \mathrm{tds}=$ Two tablets three times daily, $\mathrm{n}=$ Number of subjects

This established finding is further illustrated with a bar chart as shown in Figure-2 


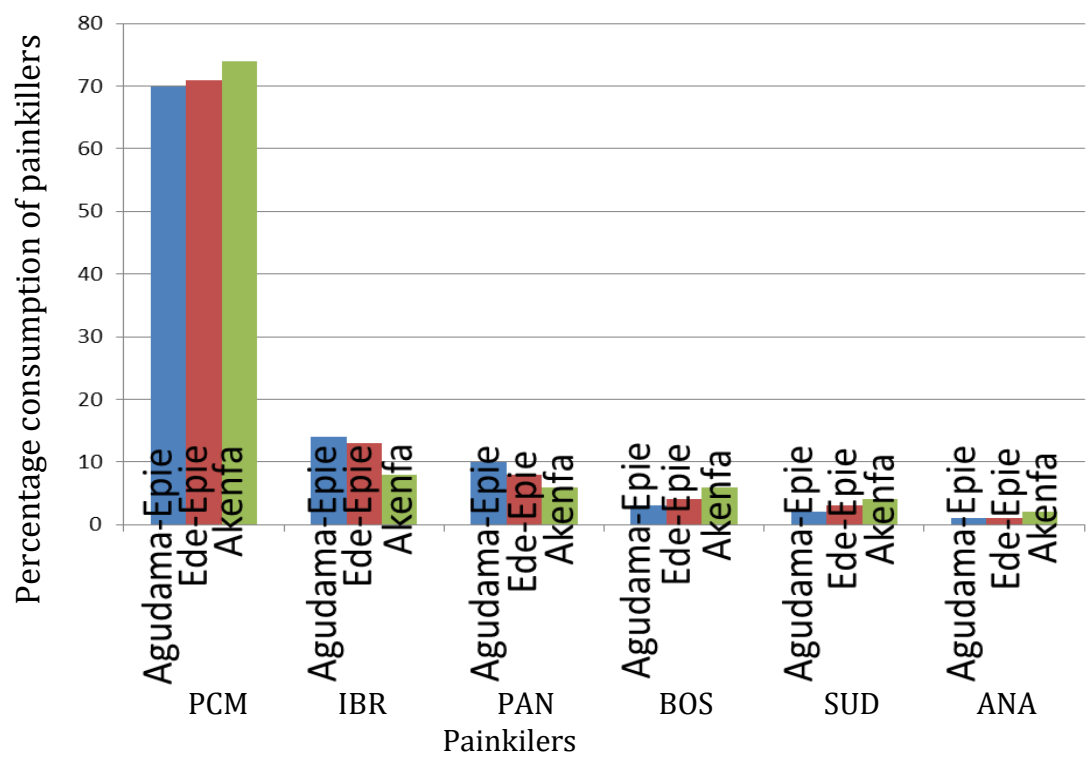

Figure $2 \mathrm{~A}$ bar chart showing the percentage consumption of some painkillers in the study communities in Yenagoa.

Keys PCM = Paracetamol (acetaminophen); IBR = Ibuprofen; PAN = Panadol extra; BOS = Boska; SUD = Sudrex; ANA = Anacin

As shown in Table 2, this study went further to reveal that 70-73\% of the consumers of paracetamol (acetaminophen) in the study communities are traders by occupation, while $15-19 \%$ are farmers, $7-11 \%$ are students and $1-5 \%$ are office workers. These findings as established in this present study show that traders are the most indiscriminate consumers of paracetamol (acetaminophen) in the study communities which may be attributed to the daily rigorous work that may in turn lead to stress and body pain, regular availability and cheapness of this tablet in patent medicine stores as well as a major gap in knowledge as regards the proper and well guided consumption of this tablet.

Table 2 Prevalence of paracetamol (acetaminophen) tablet consumption with reference to the occupational status of consumers (volunteers) in the study communities in Yenagoa, Bayelsa State, Nigeria

\begin{tabular}{|c|c|c|c|}
\hline Communities & Occupational status & $\begin{array}{ll}\text { Number } & \text { of } \\
\text { consumers } & \end{array}$ & Percentage \\
\hline \multirow[t]{4}{*}{ Agudama-Epie (n=103) } & Traders & 73 & 71 \\
\hline & Farmers & 20 & 19 \\
\hline & Students & 7 & 7 \\
\hline & Office workers & 3 & 3 \\
\hline \multirow[t]{4}{*}{ Ede-Epie (n=91) } & Traders & 66 & 73 \\
\hline & Farmers & 14 & 15 \\
\hline & Students & 10 & 11 \\
\hline & Office workers & 1 & 1 \\
\hline \multirow[t]{4}{*}{ Akenfa $(n=81)$} & Traders & 57 & 70 \\
\hline & Farmers & 12 & 15 \\
\hline & Students & 8 & 10 \\
\hline & Office workers & 4 & 5 \\
\hline
\end{tabular}

KEYS: $\mathrm{n}=$ Number of subjects

This established finding is further illustrated with a bar chart as shown in Figure-3 


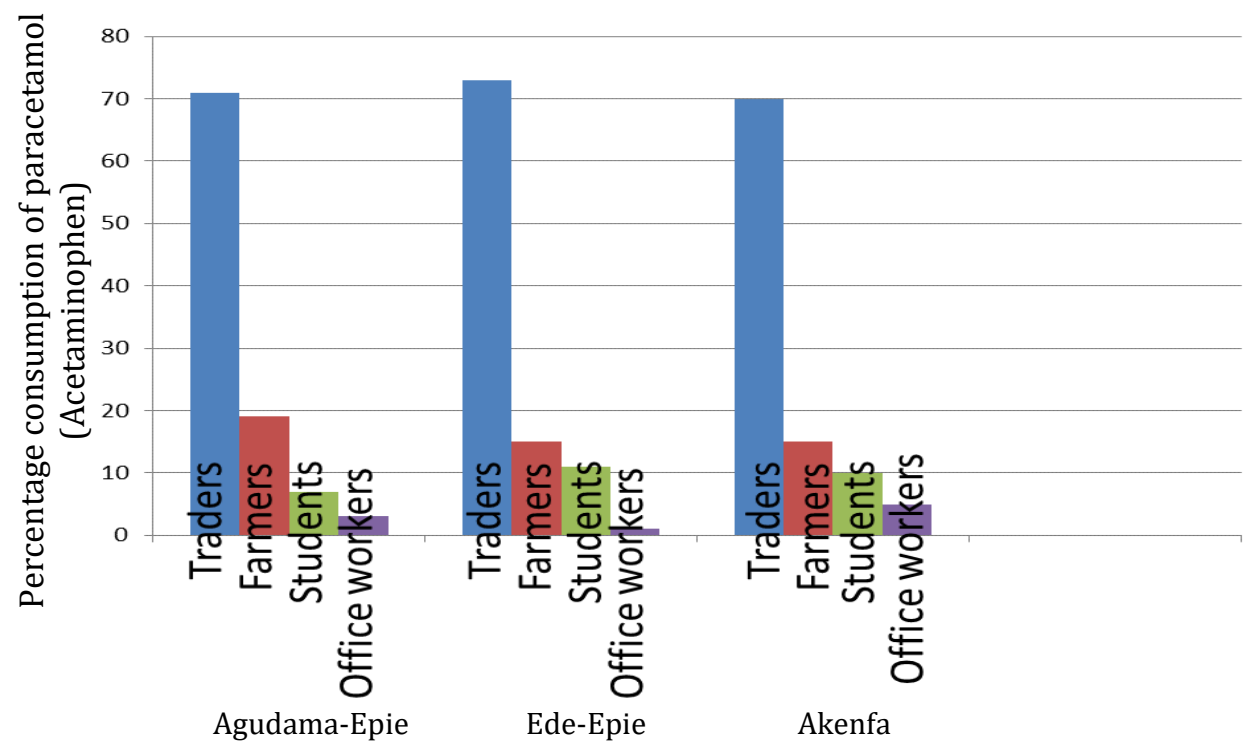

Figure $3 \mathrm{~A}$ bar chart showing the percentage consumption of paracetamol (acetaminophen) by volunteers in the study communities in Yenagoa with respect to their occupations.

The results of the biochemical parameters measured in the Rattus norvegicus rats in experimental group one (acute toxicity study), experimental group two (sub-chronic toxicity study) and experimental group three (recommended therapeutic dose study) as compared with that of the control group are as shown in Tables 3, 4 and 5 respectively

In this study the concentrations of aspartate aminotransferase, alanine aminotransferase, alkaline phosphatase, urea, creatinine, C-reactive protein and testosterone were quantitatively measured in the plasma of Rattus norvegicus rats administered with $500 \mathrm{mg} / 2 \mathrm{ml}$ paracetamol (acetaminophen) as a single dose for one day (acute toxicity study), $50 \mathrm{mg} / 2 \mathrm{ml}$ paracetamol (acetaminophen) on daily basis for thirty days (sub-chronic toxicity study) and $50 \mathrm{mg} / 2 \mathrm{ml}$ paracetamol (acetaminophen) on daily basis for three days (recommended therapeutic study) as compared with that of the Rattus norvegicus rats that were not administered with paracetamol (acetaminophen) tablet or any other drugs (control group). This however, is in a bid to assess the status of the liver (aspartate aminotransferase, alanine aminotrasferase and alkaline phosphatase) which is responsible for the metabolism of drugs, to assess the status of the kidneys (urea and creatinine) which are responsible for the excretion of metabolic waste products, to assess any inflammatory response (C-reactive protein) that may manifest during the course of the study and to assess the status of the reproductive organs to produce sperm (testosterone).

As shown in Table 3 the mean values of liver enzymes, aspartate aminotransferase, alanine aminotransferase and alkaline phosphatase revealed significant elevations $(\mathrm{p}<0.05)$ statistically in the Rattus norvegicus rats that were administered with $500 \mathrm{mg} / 2 \mathrm{ml}$ of paracetamol (acetaminophen)/ $1.23 \mathrm{~g}$ body weight for one day (acute toxicity study) as compared with that of the Rattus norvegicus rats that were not administered with paracetamol (acetaminophen) or any other drug (control group). This finding as established in this present study may be suggestive of liver injury which has led to the leakage of these intracellular enzymes from the liver to the plasma thus accounting for their elevated concentrations

Also as shown in Table 3, the mean values of urea and creatinine revealed significant elevations $(\mathrm{p}<0.05)$ statistically in the Rattus norvegicus rats that were administered with $500 \mathrm{mg} / 2 \mathrm{ml}$ of paracetamol (acetaminophen)/1.23g body weight for one day (acute toxicity study) as compared with that of the Rattus norvegicus rats that were not administered with paracetamol (acetaminophen) or any other drug (control group). This finding as established in this present study may compromise the functional and structural integrity of the kidneys with the subsequent accumulation of waste products of metabolism and loss of the kidneys sensitive homeostatic mechanisms which had in turn led to the elevation of these renal biochemical parameters

The mean value of $\mathrm{C}$-reactive protein as shown in Table 3 revealed significant elevation $(\mathrm{p}<0.05)$ statistically in the Rattus norvegicus rats that were administered with $500 \mathrm{mg} / 2 \mathrm{ml}$ of paracetamol (acetaminophen)/1.23g body weight for one day (acute toxicity study) as compared with that of Rattus norvegicus rats that were not administered with paracetamol (acetaminophen) or any other drug (control group). This finding which is established in this present study 
is presumed to be linked with the release of interleukin-6 as well as some cytokines which had subsequently influenced the synthesis of this protein.

As shown in Table 3, the mean value of testosterone revealed significant decrease $(\mathrm{p}<0.05)$ statistically in the Rattus norvegicus administered with $500 \mathrm{mg} / 2 \mathrm{ml}$ of paracetamol (acetaminophen) $/ 1.23 \mathrm{~g}$ body weight for one day (acute toxicity study) as compared with that of Rattus norvegicus rats that were not administered with paracetamol (acetaminophen) or any other drug (control group). This finding as established in this present study may be suggestive of the adverse effect of the acute dosage of paracetamol (acetaminophen) on spermatogenesis which may be associated with the degeneration and disruption of the seminiferous tubules germ cells as well as the Leydig cells.

Table 3 Results of biochemical parameters in plasma of Rattus norvegicus rats following the consumption of $500 \mathrm{mg} / 2 \mathrm{ml}$ paracetamol (acetaminophen) tablet for one day (acute toxicity study) compared with that of the control rats

\begin{tabular}{|c|c|c|c|c|}
\hline Parameters & $\begin{array}{l}\text { Control group ( } n=6 \\
\text { ) }\end{array}$ & $\begin{array}{l}\text { Experimental group } \\
(n=6)\end{array}$ & p-values & Remarks \\
\hline AST (U/L) & $6.70 \pm 2.06$ & $15.90 \pm 2.73$ & $\mathrm{p}<0.05$ & $S$ \\
\hline $\operatorname{ALT}(\mathrm{U} / \mathrm{L})$ & $6.91 \pm 2.83$ & $21.60 \pm 3.69$ & $\mathrm{p}<0.05$ & $\mathrm{~S}$ \\
\hline ALP (IU/L) & $20.82 \pm 3.49$ & $44.33 \pm 5.14$ & $\mathrm{p}<0.05$ & S \\
\hline Urea (mmol/L) & $3.93 \pm 1.46$ & $11.67 \pm 1.70$ & $\mathrm{p}<0.05$ & $\mathrm{~S}$ \\
\hline Creatinine $(\mathrm{mmol} / \mathrm{L})$ & $59.10 \pm 4,29$ & $106.00 \pm 4.82$ & $\mathrm{p}<0.05$ & $\mathrm{~S}$ \\
\hline $\operatorname{Crp}(\mathrm{mg} / \mathrm{L})$ & $2.40 \pm 0.96$ & $5.20 \pm 1.72$ & $\mathrm{p}<0.05$ & S \\
\hline Testosterone(ng/ml) & $3.50 \pm 0.85$ & $2.60 \pm 0.56$ & $\mathrm{p}<0.05$ & $\mathrm{~S}$ \\
\hline
\end{tabular}

KEYS: Values are in means \pm Standard Deviation (SD), AST $=$ Aspartate aminotransferase, ALT $=$ Alanine aminotransferase, ALP $=$ Alkaline phosphatase, $\mathrm{Crp}=\mathrm{C}$-reactive protein, $\mathrm{S}=$ Statistically significant, $\mathrm{n}=$ Number of rats

This study went further as shown in Table 4 to reveal statistically significant elevations $(\mathrm{p}<0.05)$ in the mean values of all the measured biochemical parameters in Rattus norvegicus rats administered with $50 \mathrm{mg} / 2 \mathrm{ml}$ paracetamol (acetaminophen) on daily basis for thirty days (sub-chronic toxicity study) as compared with that of the Rattus norvegicus rats in the control group. These findings are as established in this study.

Table 4 Results of biochemical parameters in plasma of Rattus norvegicus rats following the consumption of $50 \mathrm{mg} / 2 \mathrm{ml}$ paracetamol (acetaminophen) tablet on daily basis for thirty days (sub-chronic toxicity study) compared with that of the control

\begin{tabular}{|l|c|c|c|c|}
\hline Parameters & $\begin{array}{l}\text { Control group } \\
\text { (n=6) }\end{array}$ & $\begin{array}{l}\text { Experimental } \\
\text { group (n=6) }\end{array}$ & p-values & Remarks \\
\hline AST (U/L) & $6.70 \pm 2.06$ & $24.84 \pm 2.91$ & $\mathrm{p}<0.05$ & $\mathrm{~S}$ \\
\hline ALT (U/L) & $6.91 \pm 2.83$ & $30.10 \pm 4.29$ & $\mathrm{p}<0.05$ & $\mathrm{~S}$ \\
\hline ALP (IU/L) & $20.82 \pm 3.49$ & $49.52 \pm 5.94$ & $\mathrm{p}<0.05$ & $\mathrm{~S}$ \\
\hline Urea (mmol/L) & $3.93 \pm 1.46$ & $15.21 \pm 2.67$ & $\mathrm{p}<0.05$ & $\mathrm{~S}$ \\
\hline Creatinine (mmol/L) & $59.10 \pm 4,29$ & $129.00 \pm 5.82$ & $\mathrm{p}<0.05$ & $\mathrm{~S}$ \\
\hline Crp (mg/L) & $2.40 \pm 0.96$ & $7.80 \pm 2.65$ & $\mathrm{p}<0.05$ & $\mathrm{~S}$ \\
\hline Testosterone(ng/ml) & $3.50 \pm 0.85$ & $2.10 \pm 0.32$ & $\mathrm{p}<0.05$ & $\mathrm{~S}$ \\
\hline
\end{tabular}

KEYS: Values are in means \pm Standard Deviation (SD), AST $=$ Aspartate aminotransferase, ALT = Alanine aminotransferase, ALP $=$ Alkaline phosphatase, $\operatorname{Crp}=\mathrm{C}$-reactive protein, $\mathrm{S}=$ Statistically significant, $\mathrm{n}=$ Number of rats

As shown in Table 5, the mean values of all the measured biochemical parameters revealed no statistically significant differences ( $\mathrm{p}>0.05$ ) in the Rattus norvegicus rats administered with $50 \mathrm{mg} / 2 \mathrm{ml}$ paracetamol (acetaminophen) on daily basis for three days (recommended therapeutic dose study) as compared with that of the control Rattus norvegicus rats. This is as established in this study. 
Table 5 Results of biochemical parameters in plasma of Rattus norvegicus rats following the consumption of $50 \mathrm{mg} / 2 \mathrm{ml}$ paracetamol (acetaminophen) tablet on daily basis for three days (recommended therapeutic dose) compared with that of the control rats.

\begin{tabular}{|l|l|l|l|c|}
\hline Parameters & $\begin{array}{l}\text { Control group } \\
(\mathbf{n = 6})\end{array}$ & $\begin{array}{l}\text { Experimental } \\
\text { group (n=6) }\end{array}$ & p-values & Remarks \\
\hline AST (U/L) & $6.70 \pm 2.06$ & $6.74 \pm 2.08$ & $\mathrm{p}>0.05$ & $\mathrm{NS}$ \\
\hline ALT (U/L) & $6.91 \pm 2.83$ & $6.93 \pm 2.84$ & $\mathrm{p}>0.05$ & $\mathrm{NS}$ \\
\hline ALP (IU/L) & $20.82 \pm 3.49$ & $20.84 \pm 3.50$ & $\mathrm{p}>0.05$ & $\mathrm{NS}$ \\
\hline Urea (mmol/L) & $3.93 \pm 1.46$ & $3.94 \pm 1.48$ & $\mathrm{p}>0.05$ & $\mathrm{NS}$ \\
\hline Creatinine (mmol/L) & $59.10 \pm 4,29$ & $59.12 \pm 4.30$ & $\mathrm{p}>0.05$ & $\mathrm{NS}$ \\
\hline Crp (mg/L) & $2.40 \pm 0.96$ & $2.43 \pm 0.98$ & $\mathrm{p}>0.05$ & $\mathrm{NS}$ \\
\hline Testosterone(ng/ml) & $3.50 \pm 0.85$ & $3.51 \pm 0.87$ & $\mathrm{p}>0.05$ & $\mathrm{NS}$ \\
\hline
\end{tabular}

KEYS: Values are in means \pm Standard Deviation (SD), AST $=$ Aspartate aminotransferase, ALT = Alanine aminotransferase, ALP $=$ Alkaline phosphatase, $\operatorname{Crp}=$ C-reactive protein, NS = Not statistically significant, $n=$ Number of rats

\section{Conclusion}

In conclusion, this present study has revealed that paracetamol (acetaminophen) is indiscriminately consumed by traders in the study communities and its indiscriminate consumption by Rattus norvegicus rats revealed hepato - renal, inflammatory and spermatogenesis disorders which has given an insight on the presumable danger its indiscriminate consumption may pose to human health. However, its consumption in therapeutic recommended dose was well tolerated by the Rattus norvegicus rats.

\section{Recommendations}

- Further research on histomorphological examination of the liver, kidney and testes is recommended so as to ascertain the true picture and extent of damage to these vital organs as a result of the one day consumption of $500 \mathrm{mg} / 2 \mathrm{ml}$ paracetanol (acetaminophen)/1.23g body weight, acute toxicity study and thirty days consecutive consumption of $50 \mathrm{mg} / 2 \mathrm{ml}$ paracetanol (acetaminophen)/1,23g body weight, sub-chronic toxicity study by the Rattus norvegicus rats.

- The public should be enlightened by the appropriate authorities on the likely danger associated with the indiscriminate use of paracetamol (acetaminophen) without the prescription of a medical doctor or health professional.

- Paracetamol (acetaminophen) is a composition of many painkillers as well as combination medicines that are sold over the counter, it is therefore vital to ensure that the recommended dosage is not exceeded when a variety of medication is taken.

\section{Compliance with ethical standards}

\section{Acknowledgments}

I hereby acknowledge with thanks all the volunteers that availed themselves for this study, the leadership of National Association of Proprietary and Medicine Dealers Association Bayelsa State branch, Nigeria as well as Mr Samuel Anakwe Chukwuma for helping to anaesthetize the Rattus norvegicus rats used for this study. Also I acknowledge with thanks all those who assisted me financially in the execution of this study

\section{Disclosure of conflict of interest}

No conflict of interest

\section{Statement of ethical approval}

All the procedures carried by the author in respect of this study were strictly in compliance with the Principle of Helsinki declaration of 1975 as revised in 2018 (human study) and in accordance with the ethical standards of National 
Guidelines for animal usage in research. The author Emmanuel Tonbra Egoro was fully involved in the concept and design of the study as well as the analysis and interpretation of data. He was also responsible for the critical revision for the important intellectual content and final approval for the submission of this manuscript for publication

\section{References}

[1] Altinoz SMA, Korkmaz A, NF-kappa B. Macrophage migration inhibitory factor and cyclooxygenase-inhibitions as likely mechanisms behind the acetaminophen and NSAID-prevention of ovarian cancer. .Journal of neoplasma. 2004; 51 (4): 239-247.

[2] Byrant, Bronwen, Knights, Katleen, Salerno Evelyn. Pharmacology for health professionals. Elsevier. $2007 ; 270$.

[3] Hochhauser, Daniel. Cancer and its management. America 7th ed. John Wiley and Son publishers. $2014 ; 119$.

[4] Ubaldo CD, Hall NS, Le B. Postmarketing review of intravenous acetaminophen dosing base on food and drug administration prescribing guidelines. Journal of human pharmarcology and drug therapy. 2014; 34(1): 34-39.

[5] Prescott LP. Paracetamol over dose .pharmacological considerations and clinical management. Bristish journal of clinical pharmacology. 1983; 25(4): 290-314.

[6] Das J, Ghosh J, Manna P, Sil PC. Taurine protects acetaminophen-induced oxidative damage in mice kidney through paracetaminophen urinary excretion and cyp2e1 inactivation. Toxicology. 2010; 269: 24-34.

[7] Waring WS. Novel acetylcysteine regimens for treatment of paracetamol overdose. Therapeutic advance drug safety. 2012; 3: 305-331.

[8] Blantz RC. Acetaminophen: acute and chronic effects on renal function. America journal of kidney disease. 1996; 28: 3-6.

[9] Kheradpezhouh E, Panjehshahin MR, Miri R, Javidnia K, Noorafshan A, Monabati A, Dehpour AR. Curcumin protects rats against acetaminophen-induced hepatorenal damages and shows synergistic activity with n-acetyl cysteine. European journal of pharmacology. 2010; 628: 274-281.

[10] Smyth EM, Grosser T, Wang M, Yu Y, Fitz, Gerald GA. Prostanoids in health and disease. Journal of lipid research. 2009; 50(5): 423-428.

[11] Rumack B, Matthew H. Acetaminophen poisoning and toxicity. pediatrics. America journal of disease of children. 1995; 55(6): 871-876.

[12] Wan NF, Wan MZ. Sample size calculation in animal studies using resource equation method, Malaysian journal of medical science. 2017; 24(5): 101-105.

[13] Dede EB, Kagbo H.D, Igbigbi PS. Determination of LD50 value of metakelfin in rats. Journal of science and metascience. $1997 ; 1: 1-7$.

[14] Matsumura F. Mode of action of insecticide in toxicology of insecticides. New York: Plenum publishers. 1975; 105-134.

[15] Ifenkwe JC, Nwanjo HU, Nwosu DC, Solomon EA, Bot YS. Heavy metals bioaccumulation and lipid peroxidation damage in residents of gas flaring community. International journal of advances in scientific research and engineering. 2018; 4(7): 140-150.

[16] Egoro ET, Oni ES, Chukwuma SA. Studies on selected biochemical and hormonal profile status in plasma of some roadside welders in Ajegunle, Nigeria. Global journal of medical research (K). 2019; 19(6): 17-23.

[17] Tijani AA, Adekomi DA, Owoyale MO. Histological changes in the vital organs of male rats following short term exposure to smoke extract of canabis sativa. Research journal of health sciences. 2014; 2(2): 90-95. 